\title{
The formation of borate deposits in Da Qaidam Salt Lake of Qaidam Basin, Tibetan Plateau: boron isotopic and hydroclimatic constraints
}

\author{
CHUNLIANG GAO ${ }^{1,2}$, JUNQING YU ${ }^{1,2}$, AIYING CHENG ${ }^{1,2}$, LISHA \\ ZHANG $^{1,2}$ \\ ${ }^{1}$ Qinghai Provincial Key Laboratory of Geology and Environment \\ of Salt Lakes, Qinghai Institute of Salt Lakes, Chinese \\ Academy of Sciences, Xining 810008, China \\ ${ }^{2}$ Qinghai Provincial Key Laboratory of Geology and Environment \\ of Salt Lakes, Qinghai Institute of Salt Lakes, Chinese \\ Academy of Sciences, Xining 810008, China \\ E-mail: chunlianggao@isl.ac.cn
}

This study focused on the pinnoite, ulexite and hydroboracite from Da Qaidam Salt Lake, through multi-index methods including mineralogy and geochemistry, aiming to interpret the mechanism of pinnoite and other borate minerals. The results showed that the ${ }^{11} \mathrm{~B} /{ }^{10} \mathrm{~B}$ value of pinnoite ore in lakebed was 3.9962 with the $\delta^{11} \mathrm{~B}$ value is $-13.30 \%$; the ${ }^{11} \mathrm{~B} /{ }^{10} \mathrm{~B}$ value of ulexite ore in lakeside was 4.0121 with the $\delta^{11} \mathrm{~B}$ value is $-7.80 \%$; the ${ }^{11} \mathrm{~B} /{ }^{10} \mathrm{~B}$ value of hydroboracite ore in lakeside was 4.0063 with the $\delta^{11} \mathrm{~B}$ value is $9.23 \%$. The isotopic evidences indicated that the different borate minerals formed in the different brine concentration stages with different hydrochemical compositions. The borate minerals are formed in the lake environment with specific hydrogeochemical conditions (e.g., alkaline brine, hydrochemical types, boron concentration, boron ions, $\mathrm{Mg} / \mathrm{Ca}$ ratio, dilution and mixing mechanism). The hydrological response to climate warming in high altitude mountain catchments contrasts strikingly to that in the hyper-arid Qaidam Basin, which is the key hydroclimatic driving factor. Consequently, due to the favorable hydrogeochemical conditions, the borate deposits finally formed in different zones of Da Qaidam Salt Lake. Therefore, the borate formation was controlled by a coupling mechanism, i.e., the inherent geochemical characteristics and the external conditions.

This work was supported by the National Natural Science Foundation of China (41501052, U1407206, 41471013), and Qinghai Natural Science Foundation of China (2017-ZJ_928Q).

Keywords: Pinnoite ore, Ulexite ore, Hydroboracite ore, Boron isotopic composition, Da Qaidam Salt Lake, Qaidam Basin 